\title{
Róża DzıEwa
}

\section{The Issue of Eviction and the Related Problems of Social Housing in the Polish Legal System}

Evictions related to contractual tenancy are an escalating problem in Poland which cannot be ignored. The relevant provisions of the law seem to fully protect the interests of both the landlord and the tenant. However, the application of the law and the circumstances of eviction indicate the need for change. The issue is important because this is where the influences of three different parties intertwine: the owner of a rental property, who under a lease contract leases it to a third party; the tenant; and the commune, which performs basic functions in the field of public tasks of local importance in its own name and according to its own responsibility. In order to effectively perform an eviction, all the above-mentioned parties have to cooperate. The role of the commune is particularly significant here since improper performance of its public tasks in the field of the provision of social or temporary housing units may lead to situations where, despite a legally binding eviction ruling, the person entitled to the property cannot exercise their right of ownership.

\section{What is eviction?}

The issue of eviction is essentially regulated by the Tenants' Rights, Municipal Housing Stock and the Civil Code Amendment Act of 21 June 2001 ${ }^{1}$ (Hereinafter referred to as the Tenants' Rights Act). Provisions of the Civil Code and the Code of Civil Procedure (procedural issues) apply to all matters not settled therein. Article $222 \S 1$ of the Civil Code (stating the basis for eviction) is particularly significant. In accordance with this article, the owner can demand that the person who factually possesses the owner's object deliver it to the owner, unless the person holds an effective right to possess the object.

1 Dz. U. 2005, No. 31, item 266. 
Although the Tenants' Rights Act does not explicitly define eviction, the interpretation of its provisions allows one to conclude that they constitute all factual and legal actions that aim to clear the rental or real property of people and objects and to deliver it to the entitled person ${ }^{2}$. The situation recognised as the basis for demanding eviction is where a person occupies a property without the legal title. This may involve occupying a real property without due authorisation as well as expiry of the legal relationship (e.g. as a result of termination of the lease contract). In special cases the entitled person may demand that the person who has the legal title to the property leave the said property provided that a special provision applies, e.g. it is necessary to conduct renovation works or safety is at risk due to the technical state of the building ${ }^{3}$. However, the most common cause of eviction is when tenants are in arrears due to insufficient financial resources necessary for timely payment of the rent ${ }^{4}$.

The procedure for performing an eviction can be generally divided into two stages ${ }^{5}$. The first one is of a preparatory nature and involves the following:

- default notice under pain of termination of the lease contract;

- termination of the lease contract and notice to vacate;

- action for termination of the legal relationship and for vacating the property.

The second stage is the enforcement proceedings conducted by the court enforcement officer, upon a motion by the entitled person based on a ruling registered for enforcement and the commune's potential liability for damages.

\subsection{First stage of eviction}

Pursuant to article 11 paragraph 1 of the Tenants' Rights Act, if the tenant is entitled to paid use of a property, the owner can terminate the legal relationship only under conditions stated in article $2-5$ and article 21 paragraph 4 and 5 therein. Those provisions protect the tenant against sudden termination of the legal relationship under which the tenant uses the property. The principal grounds for terminating a lease or any other relationship which entitles one to use a property are specified in paragraph 2 of the $\operatorname{article}^{6}$. Pursuant to the provision, the owner can terminate the legal relationship if, despite a written notice, the tenant continues to use the property contrary to its intended purpose or in a way that is contrary to the agreement; neglects their duties and thus causes damage to the property;

2 P. Rola, Eksmisja - niektóre zagadnienia prawne, Nieruchomości 3/2007, p. 6.

3 A. Banowicz, Rules of eviction [online]. Serwis prawa [access: 2013-12-20]. Available at: www. serwisprawa.p1/artykuly,28,12283,zasady-eksmisji.

4 Cf. J. Krasnodembski, How are tenants' rights protected [online]. Infor [access: 2013-00-00]. Available at: www.infor.pl ; R. Krupa-Dąbrowska, How to evict from a social housing unit, Rzeczpospolita 2013-04-08.

5 P. Rola, op.cit., p. 6.

6 R. Dziczek, Ochrona praw lokatorów. Dodatki mieszkaniowe, Komentarz. Wzory pozwów, wyd. 5, Warszawa 2012, p. 107. 
damages equipment intended for the common use of tenants; violates the house regulations in an obvious and persistent manner, making the use of other properties inconvenient; is in arrears with rent or other dwelling costs for the minimum of three full payment periods; has subleased or assigned the use of the property or part of it free of charge to third parties without the written permission of the owner; or continues to use property which needs to be vacated due to the necessity of demolition or renovation of the building. Termination should be effected in writing under pain of nullity and should state the reason for termination (article 11 paragraph 1 sentence 2). One cannot fail to notice that the provision of article 11 of the Tenants' Rights Act uses terms relevant to the lease contract since it is a fundamental type of contract of paid use of residential premises ${ }^{7}$.

At the same time, article 11 of the Tenants' Rights Act imposes limits on the freedom of the landlord to terminate legal relationships regarding housing which are based on a contract of paid use of a real property ${ }^{8}$. It does not, however, impose any limits on terminating such relationships by the tenant. Thus, the various limitations introduced by way of the said provision are not binding for the tenant, since the tenant can terminate the contract at any time and the relevant issues concerning the basis and period of notice are regulated by the provisions concerning a particular legal relationship (i.e. in the case of a lease, provisions of the Civil Code concerning the lease apply).

The landlord can overcome the said limitations only by following the general rule by which all contracts, including contracts of using a real property, can be terminated by mutual agreement of the parties 9 . A reference to the rule appears in article 11 paragraph 10 of the Tenants' Rights Act, under which, provided that the parties were not able to reach agreement as to the terms and date of the termination of the relationship, due to compelling reasons other than those stated in article 11 paragraph, 2, the owner can file a petition to terminate the legal relationship and order removal of the tenant from the property. It should be remembered that in such matters the defendants are all the persons for whom the property is their place of residence.

The ruling terminating the legal relationship of property use is of a constitutive nature $^{10}$. When terminating the lease, the court usually obligates the defendant to vacate the property, and determines whether they are entitled to a social or alternative housing unit or suspends eviction ( $c f$. article 302 of the Civil Code $)^{11}$.

7 R. Dziczek, op. cit., p. 104.

8 A. Doliwa, Prawo mieszkaniowe. Komentarz, wyd. 4, Warszawa 2012, p. 211.

9 Ibidem., p. 212.

10 J. Chaciński, Ochrona praw lokatorów. Komentarz, wyd. 3, Warszawa 2013, p. 127.

11 R. Dziczek, op. cit., p. 108. 


\subsection{Second stage of eviction}

As has been mentioned earlier, the second stage of eviction involves the enforcement proceedings. The task of performing eviction has been assigned to public authorities, more specifically - to the court enforcement officer or an administrative law enforcement authority. It can be conducted on the basis of either the provisions of the Civil Code or the Act on Administrative Enforcement Proceedings, depending on the nature of the duty or the properties of the judicial authority ${ }^{12}$. The intention behind this regulation is to avoid any lawlessness and to protect the interests of the evicted person.

In cases where the evicted person has been granted the right to a social housing unit under the court's ruling, the court enforcement officer can only evict the person where such a housing unit is available. Therefore, in performing the duty of vacating the property which the debtor uses as their place of residence on the basis of the writ of execution, the court enforcement officer must suspend their actions until the commune designates the said social or temporary housing unit ${ }^{13}$. This is because, pursuant to article 14 paragraph 1 sentence 2 of the Tenants' Rights Act, it is the responsibility of the commune responsible for the location of the vacated property to provide social housing. The evicted person can thus refuse to be relocated to a social housing unit offered by a different entity. Furthermore, failure to fulfil the said duty can subject the commune to liability for damages to the property owner, for whom the ruling in force cannot be executed.

\section{The issue of social housing}

The definition of a social housing unit appears in article 2 paragraph 1 subp. 5 of the Tenants' Rights Act, under which each mention of a social housing unit therein shall be construed as a residential property suitable for use as a dwelling with respect to the fixtures and fittings and the property's technical state. Additionally, the floor area of the rooms per each of the tenant's household members cannot be smaller than $5 \mathrm{~m}^{2}$ or $10 \mathrm{~m}^{2}$ in the case of a single-person household, and the standard of the housing unit can be below that of the property the person has been evicted from.

As has been mentioned earlier, in the eviction ruling the court determines whether the tenant is entitled to a social housing unit. The court investigates ex officio whether there are grounds for providing the tenant with a social housing unit. During the adjudication, the court takes into consideration the current use of the property as well as the defendant's financial and family situation (article 14 paragraph 3 of the Tenants' Rights Act). It is important to note that as of 2005 there are no more sidewalk evictions in Poland, i.e. evictions without providing the tenant with a temporary housing unit.

12 P. Rola, op. cit., p. 6.

13 Cf. M. Bielecki, Metody skutecznej eksmisji niechcianego lokatora, Nieruchomości 8/2006, p. 6. 
The practice was common in the 1990s. Pursuant to article $1046 \S 4$ of the Code of the Civil Procedure, if performing the duty of vacating the property which the debtor uses as their place of residence on the basis of the writ of execution, which does not grant the debtor the right to a social or temporary housing unit, the court enforcement officer should evict the debtor and relocate them to a different property to which they have the legal title and where they can reside. If, however, the debtor is not entitled to a different property where they could reside, the court enforcement official suspends their actions until the commune responsible for the location of the vacated property, upon a motion by the officer, designates a temporary housing unit for the debtor, but not longer than for the period of 6 months. After that time, the officer evicts the debtor and relocates them to a night shelter, a homeless shelter or a different establishment offering temporary residence designated by the commune competent for the location of the vacated property. Upon relocating the debtor to a night shelter, a shelter or a different establishment offering temporary residence, the officer should inform the competent commune of the need to provide the debtor with temporary accommodation.

One cannot fail to notice that the above-mentioned regulation shifts the duty of supporting the tenant until they are provided with a temporary housing unit onto the property owner, whereas in the case of eviction rulings which involve an order to provide temporary housing, the property owner has the right to demand compensation from the commune for failing to provide a social housing unit ${ }^{14}$.

Pursuant to article 14 paragraph 4 of the Tenants' Rights Act, the court cannot deny entitlement to a social housing unit to the following persons:

- pregnant women;

- minors, disabled persons as defined in the provisions of the Social Assistance Act of 29 November $1990^{15}$, incapacitated persons and custodial guardians who share the household with such persons;

- bedridden persons;

- recipients of pensions who qualify for social assistance benefits;

- the registered unemployed;

- persons meeting the conditions set by the commune council by way of a resolution: unless those persons can reside in a property other than the current one.

As regards the resolution of the commune council, it should describe the rules regarding the lease of units comprising the housing resources of the commune. The basic conditions which have to be met by people applying for a social housing unit are stated, first and foremost, in Art. 23 par. 2 of the Tenants' Rights Act. The Article states that the lease contract of a social housing unit can be made with a person who has no legal

14 Cf. R. Krupa-Dąbrowska, Brak lokali socjalnych kosztuje miasta coraz więcej, Rzeczpospolita 2010-12-22.

15 Dz. U. 1998, No. 64, item 414. 
entitlement to a property and whose household income does not exceed the amount stated in the resolution of the commune council. However, an issue has been raised in the jurisdiction that the commune cannot state different conditions in its resolution that those defined by the Tenants' Rights Act ${ }^{16}$. It results from the fact that the rules of lease should be defined in such a manner that those inhabitants of the commune who fulfil the basic conditions (i.e. those included in the Act), should have an equal opportunity to try and obtain the social housing unit ${ }^{17}$.

The enforcement authority is under an obligation to determine whether the person to be evicted belongs to any of the above-mentioned groups, and if they do, the authority is obliged to inform them of the possibility of instituting a relevant legal action ${ }^{18}$. Simultaneously, the enforcement procedures should be suspended and a prosecutor notified. This way the regulation adds an additional safeguard to the implementation of rights as a result of the right granted to prosecutors by the article 55 of the Code of Civil Procedure to institute legal action on behalf of such persons ${ }^{19}$.

It is worth noting that a contract for the lease of a social housing unit can be contracted only for a definite period of time, which is designed to ensure periodic verification of the entitlement to a social housing unit. Naturally, after the end of the definite term, such a contract can be extended for another period of time, but prior to this the commune should investigate whether the tenant continues to be entitled to this form of assistance. In a case where the tenant's income exceeds the limit set by the resolution, apart from the usual rent, the commune can require the tenant to pay compensation equal to the regular rental rate for council flats ${ }^{20}$.

What is important, when determining whether the tenant is entitled to a social housing unit, is that the court orders suspension of the eviction procedure until the commune prepares a contract for lease of a social housing unit (article 14 paragraph 6 of the Tenants' Rights Act). In the meantime, the overwhelming majority of communes do not have a sufficient number of social housing units at their disposal and thus cannot give even an approximate date of providing the entitled person with accommodation. This

16 Cf. sentences of the Supreme Administrative Court in cases: I OSK 1318/2009, I OSK 598/2008, OSK 883/2004; sentence of the Voivodeship Administrative Court in Łódź, III SA/ Łd 117/2011; sentences of the Voivodeship Administrative Court in Wrocław in cases: IV SA/ Wr 389/2007, IV SA/Wr 98/2004, IV SA/Wr 388/2007; sentences of the Voivodeship Administrative Court in Gorzów Wlkp. in cases: II SA/Go 126/2011, II SA/Go 528/2011; sentence of the Voivodeship Administrative Court in Gdańsk, III SA/Gd 433/2010; sentence of the Voivodeship Administrative Court in Gliwice, IV SA/G1 685/2009.

17 Sentence of the Voivodeship Administrative Court in Gliwice, II SA/G1 1156/2010.

18 Resolution of the Polish Supreme Court, III CZP 61/07.

19 Resolution of the Polish Supreme Court, III CZP 61/07.

20 M. Kosiarski, Dla najbiedniejszych lokal socjalny, Rzeczpospolita 2012-01-13. 
situation is further exacerbated by the fact that the act does not specify the deadline by which the commune should fulfil their obligation. The regulation thus leads to relatively frequent situations where for many years the tenant entitled to a social housing unit has the right to reside in the previous property, while the owner is deprived of the possibility of taking any action and of disposing of their property at their own discretion. As a result, the owner has to tolerate their property being occupied by a person who no longer has the legal title to use the property ${ }^{21}$. Not only is it impossible for the owner to use the property, but he/she may also encounter difficulties when attempting to sell the property, since this innominate legal relationship (bearing the responsibilities related to the property) would continue for the potential buyer.

Admittedly, the provisions of article 18 of the Tenants' Rights Act prescribe that persons occupying a property without the relevant legal title should pay compensation until the day they vacate the property (paragraph 1). The regulation discussed applies only to those instances, in which the people occupying the social housing unit had an earlier legal entitlement to it, which subsequently expired ${ }^{22}$. The compensation should equal the rent the owner could earn for renting the property, and if the compensation does not cover the loss suffered, the owner can demand supplementary compensation from the person occupying the property (paragraph 2). In the event of a trial it will be necessary to admit the evidence based on the judicial expert's opinion ${ }^{23}$. However, as has been noted earlier, persons awaiting eviction usually fail to pay the rent and bills; therefore, it is the owner who becomes responsible for supporting them and this results in substantial financial losses ${ }^{24}$. The owner is thus forced to give credit to their previous tenant and simultaneously incurs the costs related to the property ${ }^{25}$. For this reason, property owners increasingly (often even in the first place $^{26}$ ) use the possibility given to them by art. 18 par. 5 of the Tenants' Rights Act, under which, if the commune fails to provide a social housing unit to a person entitled to it under the court's ruling, the owner can claim damages from the commune. However, the compensation covers the full amount

21 Cf. A. Doliwa, op. cit., p. 243.

22 A. Doliwa, Najem lokali. Komentarz [Property lease. Commentary], Warszawa 2010, p. 315-316; see also: resolution of the Seven Judges of the Supreme Court, III CZP 6/2005; resolution of the Supreme Court, III CZP 66/2001.

23 J. Chaciński, op. cit., p. 144.

24 Cf. R. Krupa-Dąbrowska, Brak lokali socjalnych kosztuje miasta coraz więcej, Rzeczpospolita, 22.12.2010.

25 R. Krupa-Dąbrowska, Komornik nie ma dokąd wyrzucié, można domagać się odszkodowania, Rzeczpospolita, 18.07.2013.

26 Cf. B. Rakoczy, Odpowiedzialnośc za zajmowanie lokalu bez tytutu prawnego [Responsibility for occupying a flat without a legal entitlement], 1st edition, Warszawa 2011, p. 125. 
of the damage incurred ${ }^{27}$. It should be noted that the responsibility of the commune for the damage is in solidium, that is the commune will be exempt from the obligation to pay the compensation to the extent, in which it will be paid off by the evicted person ${ }^{28}$. It is important, that the entitlement to damages is not automatic by virtue of law; it is necessary that the owner institutes a legal action against the commune competent for the location of the vacated property. It is also possible to settle the issue of damages with the commune out of court $\mathrm{t}^{29}$.

A question arises what happens if the people who had been awarded the social housing unit have outstanding payments related to this unit. According to the opinion of the Supreme Court, it is necessary to grant an injunction requiring the tenant to leave the social housing unit ${ }^{30}$. In the injunction the court declares the right to a social housing unit, provided the conditions of the Act are fulfilled. Undoubtedly, such a solution is favorable for those who occupy the social housing units, but it puts the communes in a very difficult position, as they are obliged to provide such units. This sentence makes it difficult for communes to manage the units in a reasonable way, whereas Poland suffers from an insufficient number of social housing units compared to the ever growing demand.

\section{Report by the Polish Supreme Chamber of Control}

As indicated in the report by the Polish Supreme Chamber of Control (NIK) of 14 January $2011^{31}$, although communes build increasing numbers of housing units, they nevertheless fail to satisfy the growing demand. The audit covering the years 2004-2010 included 18 communes from 6 different voivodeships. The report shows that not only are there no housing units for $80 \%$ of entitled persons, but also that the state of many of the existing ones poses a threat to the life and health of residents. None of the audited communes met the social housing needs of their residents. The number of such housing units has increased in recent years, but so has demand. The auditors showed that the number of unenforced eviction rulings which grant the entitlement to a social housing unit is rising. Since the number of such housing units is insufficient, half of the audited communes paid damages to affected property owners. According to the Chamber, the financial support from the national budget provided to the communes is also insufficient.

27 Cf. sentence of the Constitutional Tribunal, P 1/08; see also: resolution of the Supreme Court, III CZP 12/12.

28 Cf. B. Rakoczy, op. cit., p. 124; see also: sentence of the Supreme Court, V CSK 31/08; resolution of the Supreme Court, III CZP 121/07; sentence of the Appeal Court in Poznań, I ACa 154/10.

29 R. Krupa-Dąbrowska, Court..., Rzeczpospolita 2013-07-18.

30 Cf. resolution of the Supreme Court, III CZP 11/13.

31 Polish Supreme Chamber of Control's Report. Information on the results of the audit of acquiring housing units for the poor, no. 179/2010/P/10/151/LLO. 
A different report prepared by the Chamber ${ }^{32}$, covering the years 2009-2011, also points to a growing number of eviction rulings granting the entitlement to a social housing unit (a rise from over 11,000 in 2009 to 15,000 in 2011) which could not be enforced due to the communes' inability to provide such housing. As a consequence, the amount of damages paid in this period still grew, which further burdened the communes' budgets. In the audited communes, the sole amount of damages paid amounted to nearly $7.5 \mathrm{mln}$ PLN at the end of 2011, which is four times the amount paid out in 2008.

The above-mentioned reports demonstrate the scale of the problem that stems from the current legal solutions. The reports prove that not only is the communes' debt rising every year, but so is the demand for social housing, which only aggravates the financial situation of the communes.

\section{Summary}

The present paper aimed to demonstrate the deteriorating situation related to eviction. The regulations in force in Poland which protect tenants against eviction greatly hinder real estate trading for owners. The lack of action on the part of communes promotes tenants' abusive activities and can, as it were, encourage intentional avoidance of paying rent, which results in the tenant's financial gain at the expense of the owner. This state of affairs leads to situations where the ownership title to a real property is seriously limited since the entitled person de facto does not derive benefits from the property he/she owns, and additionally incurs costs related to it (e.g. property tax). It should be noted that the current regulations fail to meet the growing need and, as a consequence, contribute to the mounting crisis in this area. This could lead to a critical situation where communes will be completely unable to meet the obligations imposed on them with respect to providing social housing as well as paying related damages. As a result, property owners might increasingly seek other solutions, not necessarily legitimate ones, to remove tenants from their properties. Therefore, it is necessary to create quicker and more efficient procedures that would allow the owner to reclaim the property while at the same time protecting the evicted persons. In order to rectify the situation, the creation of realistic programmes promoting social housing and the vocational activation of the evicted persons is postulated.

\section{Biographical reference:}

Róża Dziewa - is a Ph.D. student at Koźmiński University in Warsaw, Poland. In 2012, she obtained an M.A. degree in law at the Faculty of Law and Administration at the

32 Polish Supreme Chamber of Control's report, Information on the results of the audit of residential council housing management, no. 185/2012/p/12/069/KIN. 
318 | Adam Mickiewicz University Law Review

Adam Mickiewicz University in Poznań, Poland. In the following year she completed post-graduate tax studies at the Faculty of Law, Administration and Economy at the University of Wrocław. Her professional interests include, among other things, commercial law, civil law and intellectual property law.

SUMMARY

\section{The eviction and social housing in the Polish legal system}

The aim of the study is to evaluate the eviction and social housing in the Polish legal system. Presenting the selected topic the author focus on the functioning of the eviction and social housing as well as on the Report by the Polish Supreme Chamber of Control in order to prove the deteriorating of the eviction.

Keywords: eviction, social housing, Polish legal system 